Acta Protozool. (2018) 57: 215-229 www.ejournals.eu/Acta-Protozoologica doi:10.4467/16890027AP.18.016.10092

\title{
PROTOZOOLOGICA
}

LSID urn:lsid:zoobank.org:pub:AEE9D12D-06BD-4539-AD97-87343E7FDBA3

\section{Testate Amoebae from South Vietnam Waterbodies with the Description of New Species Difflugia vietnamica sp. nov.}

\author{
Hoan Q. TRANª, Yuri A. MAZEI ${ }^{\mathrm{b}, \mathrm{c}}$ \\ ${ }^{a}$ Vietnamese-Russian Tropical Center, 63 Nguyen Van Huyen, Nghia Do, Cau Giay, Ha Noi, Vietnam \\ ${ }^{\mathrm{b}}$ Department of Hydrobiology, Lomonosov Moscow State University, Moscow, Russia \\ ${ }^{c}$ Department of Zoology and Ecology, Penza State University, Penza, Russia
}

\begin{abstract}
Testate amoebae in Vietnam are still poorly investigated. We studied species composition of testate amoebae in 47 waterbodies of South Vietnam provinces including natural lakes, reservoirs, wetlands, rivers, and irrigation channels. A total of 109 species and subspecies belonging to 16 genera, 9 families were identified from 191 samples. Thirty-five species and subspecies were observed in Vietnam for the first time. New species Difflugia vietnamica sp. nov. is described. The most species-rich genera are Difflugia (46 taxa), Arcella (25) and Centropyxis (14). Centropyxis aculeata was the most common species (observed in $68.1 \%$ samples). Centropyxis aerophila sphagnicola, Arcella discoides, Difflugia schurmanni and Lesquereusia modesta were characterised by a frequency of occurrence $>20 \%$. Other species were rarer. The species accumulation curve based on the entire dataset of this work was unsaturated and well fitted by equation $\mathrm{S}=$ $19.46 N^{0.33}$. Species richness per sample in natural lakes and wetlands were significantly higher than that of rivers $(\mathrm{p}<0.001)$. The result of the Spearman rank test shows weak or statistically insignificant relationships between species richness and water temperature, $\mathrm{pH}$, dissolved oxygen, and electrical conductivity.
\end{abstract}

Keywords: testate amoebae, Difflugia vietnamica sp. nov., waterbodies, South Vietnam, species richness

\section{INTRODUCTION}

Testate amoebae of Vietnam are still poorly investigated. To date, there are only few works on testate amoebae of Vietnam, but they are scattered both in space and time (Shirota 1966, Golemansky 1979, Balik 1995, Nguyen et al. 2007, Bobrov et al. 2010; Tran 2017).

Address for correspondence: Hoan Tran, Vietnamese-Russian Tropical Center, 63 Nguyen Van Huyen, Nghia Do, Cau Giay, Ha Noi, Vietnam; E-mail: hoantran2985@gmail.com.
Shirota (1966) has found 28 species of testate amoebae in freshwater plankton of South Vietnam. Golemansky (1979) has revealed 22 psammobiotic species from Vietnamese beaches (Ha Long, Nha Trang, Phan Rang, Vung Tau) and described new species Cryptodifflugia brevicolla. Investigations of the forest of Tam Dao (province Vinh Phuc have yielded 126 species, varieties and forms of testate amoebae and three new taxa-Hyalosphenia tamdaoensis, Trinema staryi and Cyclopyxis quadratus grandis - were described as well as many rare species with restricted geographical distribution 
were recorded (Balik 1995). Since then, novel species have not been recorded from Vietnam, while new species have been continuously discovered in other Asian countries such as China (Qin et al. 2008a, b, Qin et al. 2016), Korea (Kim and Park 2016) and Japan (Bobrov et al. 2012b, Bobrov and Kosakyan 2015) in recent years. Furthermore, testate amoeba communities were studied in terms of the relationship with atmospheric heavy metals accumulated by Barbula indica in Hanoi city area (Nguyen et al. 2007).

Recently, Bobrov et al. (2010) observed 143 species and forms of testate amoebae from 68 samples of soils and lake sediments collected from Cat Tien National Park (province Dong Nai). Tran (2017) recorded 53 species, varieties and forms of testate amoebae from Bau Sen and Bau Trang lakes (province Binh Thuan). The areas covered by protistology studies in Vietnam are still very restricted. Therefore, a study on testate amoeba composition from different-type waterbodies of South Vietnam was performed in course of the present study.

\section{MATERIALS AND METHODS}

Samples were taken from different-type waterbodies of South Vietnam provinces (Fig. 1), including Khanh Hoa, Ninh Thuan, Binh Thuan, Dong Nai, Dong Thap, Ben Tre, Can Tho, Kien Giang, Bac Lieu, Ca Mau. Studied waterbodies cover broad range of water ecosystems types including natural lakes (49 samples), reservoirs (26), wetlands (32), rivers (69) and irrigation channels (8). Seven remaining samples were taken from rice paddies and pools. Samples were collected during 4 periods: 4/2015 (18 samples), 9-11/2015 (153), 4/2016 (15) and 8/2016 (5).

Samples were taken from one to ten sites in each waterbody. All sampling sites had a water depth of less than $1 \mathrm{~m}$. Water, aquatic macrophytes and surface sediments from each site were sampled and put together into plastic jars. Coordinates and hydrochemical characteristics of sampling sites were determined by Garmin GPSMAP 78sc and Hanna HI 9828, respectively. Temperature, $\mathrm{pH}$, dissolved oxygen and electrical conductivity of water in sampling sites ranged from 26 to $35.6^{\circ} \mathrm{C}, 4.6$ to $9.8,0.2$ to $19.3 \mathrm{mg} / 1$ and 23 to $19170 \mu \mathrm{s} / \mathrm{cm}$, respectively. All samples were fixed in $4 \%$ formalin.

Seven to ten replicates from each sample, $1 \mathrm{~mL}$ each, were analyzed in Petri dishes in order to study testate amoeba species composition. The light microscope Olympus CX41 equipped with Cannon EOS 650D camera was used for testate amoeba identification at 80-1000 × magnification. All measurements of new species were made using Olympus camera DP21 and imaging software cellSens Entry 1.9. Electron micrographs were made by scanning electron microscope JSM-6510 (Japan). Taxonomic keys of testate amoebae by Kudo (1939), Charman et al. (2000), Mazei and Tsyganov (2006a), Mazei and Warren $(2012,2014,2015)$ were used for species identification.
All calculations and statistical analyses were performed in the R program (Team 2017). The statistical significance level was 0.05 . The Kruskal-Wallis test was used for the statistical samples with non-normal distribution for comparison of arithmetic mean between groups. Dunn's test with Benjamini-Yekutieli adjustment was used as post hoc test after Kruskal-Wallis test. Function "specaccum" in R package "vegan" was used for species accumulation curve construction. Accumulation method was random and a number of permutations was 10000 .

Hierarchical cluster analysis (complete linkage) was performed using 'hclust' function of R package 'vegan' in order to classify main types of studied waterbodies based on species presence/absence (Oksanen et al. 2018). Sørensen indices of dissimilarity were calculated using 'hclust' function of R package 'labdsv' (Roberts 2016).

A principal component analysis (PCA) was used for data ordination. It was performed using 'PCA' function in R packages 'FactoMineR'. PCA ordination biplot was created using 'fviz_pca_biplot' function in R packages 'factoextra' (Kassambara 2017).

The Spearman rank correlation was used for studying the relationship between sample species richness and water temperature, $\mathrm{pH}$, dissolved oxygen, electrical conductivity. Only samples collected in period 9-11/2015 were used for analysis. Missing values and outliers were removed from the dataset before performing the Spearman rank correlation. The 'cor.test' function of $\mathrm{R}$ package 'Stats' was used for correlation coefficients and $p$-values calculation.

\section{RESULTS}

109 species and subspecies belonging to 16 genera and 9 families were identified from 191 samples (Supplementary Table 1). Seven testate amoebae have not been identified to species level. 35 taxa were recorded in Vietnam for the first time. Total list of testate amoebae in Vietnam now includes over 320 taxa.

The genus Difflugia was characterized by highest species richness (46 taxa), followed by Arcella (25 taxa) and Centropyxis (14 taxa) (Fig. 2). The most common species was Centropyxis aculeata (observed in $68.1 \%$ of samples). Other species with a high frequency of occurrence were Centropyxis aerophila sphagnicola (27.2\%), Arcella discoides (25.6\%), Difflugia schurmanni (20.9\%), Lesquereusia modesta (20.4\%). Remaining taxa were observed in less than $20 \%$ of samples. 31 taxa ( $16.2 \%$ of total list) were observed only in one sample.

The species accumulation curve based on the entire dataset of this work is not saturated (Supplementary Figure 1). Alpha and beta-diversity coefficients were 19.46 and 0.33 , respectively.

The analyses of species richness in natural lakes, reservoirs, wetlands, rivers, and irrigation channels indicate, that the number of testate amoebae taxa in natu- 
ral lakes was highest (Supplementary Figure 2). Wetlands and rivers were characterized by the same species richness (60 and 59 taxa respectively). 51 taxa were found in reservoirs, while in irrigation channels only 22 taxa were observed.

The result of Kruskal-Wallis test shows the existence of significant $(p<0.001)$ differences between five investigated types of waterbodies by mean species richness per sample. Results of Dunn's test show that means of species richness in natural lakes and wetlands were significantly $(\mathrm{p}<0.001)$ higher than in rivers (Fig. 3). By contrast, pairwise differences among natural lakes, wetlands, reservoirs, and irrigation channels were not statistically significant $(\mathrm{p}>0.05)$. The significant differences between rivers and reservoirs or irrigation channels also were not observed $(\mathrm{p}>0.05)$.

The result of cluster analysis indicates, that testate amoeba communities of irrigation channels differed from the others (Fig. 4). The assemblages from natural lakes, wetlands, reservoirs, and rivers are group together. At that, Sørensen similarity index between wetlands of national parks and rivers was highest.

The results of the principal component analysis are shown in Fig. 5. Axes PCA1 and PCA2 accounted for $80 \%$ of the total variance in the dataset. $\mathrm{pH}$ was most strongly correlated with PCA1, while species richness was most strongly correlated with PCA2. PCA ordination biplot (Fig. 5) shows differences among samples collected from different types of waterbodies. Convergence of river samples indicated their high similarity, while other samples were relatively dispersed in the plot.

The Spearman rank correlation coefficients between species richness and water temperature, $\mathrm{pH}$, dissolved oxygen, electrical conductivity were low and ranged from -0.40 to -0.05 . At that, only correlation coefficient between species richness and electrical conductivity was statistically significant $(\mathrm{p}<0.001)$.

A morphological description of the new species is given in the following section. The morphometric variables for this species are presented in Table 1 .

\section{Difflugia vietnamica sp. nov.}

LSID urn:1sid:zoobank.org:act:40EE4F28-F925-4B44-9C70DEB8F7D476A3

Description: Shell of medium size, ovoid to elongate-ovoid with pointed apex without horn (Figs 6, 7A, C, Supplementary Figure 3A). The shell is symmetric with axis of symmetry is the line that passes through the top and perpendicular to the apertural plane. Shells are made of small sand grains (Figs 7A-D, Supplementary Figure 3B, C). The surface of the shell is relatively smooth, the area closer to the aperture is more rugged due to some particles with larger size. The aperture is circular (Supplementary Figure 3D), the apertural width is approximately $1 / 2$ of the total body length and nearly $2 / 3$ of the body width. The shell has a circular cross-section (Fig. 6, Supplementary Figure 3D).

\section{Measurements}

Shell length 48.9-64.8 $\mu \mathrm{m}$; shell width 42.6-53.4; aperture diameter $23.4-34.8 \mu \mathrm{m}$. The population is monomorphic with low coefficients of variation of all measured morphological characteristics ranging between 3.9 and 9.2\% (Table 1). Unimodal distribution of measured morphological characteristics (Supplementary Figure 4) also confirm that all measured specimens belong to the same species.

List of associated testate amoebae: The described organism was found in associations with the following species: Arcella megastoma Penard, 1902, Centropyxis aculeata (Ehrenberg, 1832) Stein, 1857, Centropyxis aerophila sphagnicola Deflandre, 1929, Centropyxis constricta (Ehrenberg, 1841) Deflandre, 1929, Difflugia ampullula Playfair, 1918, Difflugia limnetica Penard, 1902, Difflugia penardi Hopkinson, 1909, Cucurbitella vlasinensis Ogden et Zivkovic, 1983, Netzelia corona (Wallich, 1864) Gomaa et al., 2017, Netzelia wailesi (Ogden, 1980) Meisterfeld, 1984.

Ecology: Difflugia vietnamica was found in freshwater environments in reservoirs Ma Bao (10 57.973' $\left.\mathrm{N}, 107^{\circ} 55.575^{\prime} \mathrm{E}\right)$, Ta Mon (10 51.968' N, 10748.168' E), the slow current parts of river Hau $\left(10^{\circ} 38.434^{\prime}\right.$ $\mathrm{N}, 105^{\circ} 24.089^{\prime}$ E) and irrigation channel Hoa Binh $\left(9^{\circ} 17.107^{\prime} \mathrm{N}, 105^{\circ} 37.403^{\prime} \mathrm{E}\right)$ with presence of Eichhornia crassipes, Cynodon sp., Eleusine sp. macrophytes. $\mathrm{pH}$ of the water was $>7$ in all biotopes. Electrical conductivity and dissolved oxygen show a significant variation, ranging from 74 to $1027 \mu \mathrm{s} / \mathrm{cm}$ and 0.4 to 8.5 $\mathrm{mg} / \mathrm{L}$, respectively.

Type locality: Reservoir Ma Bao $\left(10^{\circ} 57.973^{\prime} \mathrm{N}\right.$, $107^{\circ} 55.575^{\prime}$ E), Province Binh Thuan.

Type specimen: Institute of tropical ecology, Vietnamese-Russian Tropical Center. Slide № 04102015H1.

Etymology: The new species was named after the country where it was found (Vietnam).

\section{Related species - similarities and differences}

Difflugia vietnamica is easily distinguished from other species of the genus Difflugia by its shell sym- 
Table 1. Morphometric characterization of Difflugia vietnamica sp. nov. based on 140 measured specimens. Measurements in $\mu \mathrm{m}$. Shell features (Fig. 9): Lb - body length, L1 - the distance from the top to the section plane passes through the position with the largest width, L2 - the distance from the apertural plane to the section plane passes through the position with the largest width, Wb - body width, Wa apertural width, $\mathrm{Wb} / \mathrm{Lb}$ - proportion between $\mathrm{Wb}$ and $\mathrm{Lb}, \mathrm{L} 1 / \mathrm{L} 2$ - proportion between $\mathrm{L} 1$ and $\mathrm{L} 2, \mathrm{Wa} / \mathrm{Lb}$ - proportion between $\mathrm{Wa}$ and $\mathrm{Lb}$, $\mathrm{Wa} / \mathrm{Wb}$ - proportion between $\mathrm{Wa}$ and $\mathrm{Wb}$. Mean - the arithmetic mean, $\mathrm{M}$ - median, $\mathrm{SD}$ - standard deviations, $\mathrm{CV}$ - coefficient of variation (\%), Min - minimum, Max - maximum.

\begin{tabular}{lrrrrrrrrc}
\hline & $\mathrm{Lb}$ & $\mathrm{L} 1$ & $\mathrm{~L} 2$ & $\mathrm{~Wb}$ & $\mathrm{Wa}$ & $\mathrm{Wb} / \mathrm{Lb}$ & $\mathrm{L} 1 / \mathrm{L} 2$ & $\mathrm{Wa} / \mathrm{Lb}$ & $\mathrm{Wa} / \mathrm{Wb}$ \\
\hline Mean & 56.8 & 30.7 & 26.2 & 47.8 & 29.9 & 0.8 & 1.2 & 0.5 & 0.6 \\
M & 56.3 & 30.5 & 26.2 & 47.8 & 30.1 & 0.8 & 1.2 & 0.5 & 0.6 \\
$\mathrm{SD}$ & 2.8 & 2.3 & 2.4 & 1.9 & 1.9 & 0.05 & 0.2 & 0.04 & 0.05 \\
$\mathrm{CV}$ & 4.9 & 7.5 & 9.2 & 3.9 & 6.4 & 6.4 & 16.7 & 8 & 8.3 \\
Min & 48.9 & 25.1 & 19.6 & 42.6 & 23.4 & 0.7 & 0.9 & 0.4 & 0.5 \\
Max & 64.8 & 37.1 & 33.2 & 53.4 & 34.8 & 1.0 & 1.8 & 0.7 & 0.8 \\
\hline
\end{tabular}

metry, pointed apex without forming a horn and a large aperture in comparison with shell width (shell width: aperture diameter ratio). Monomorphism of the new species also allows it to be easily identified.

The most similar species are Difflugia amphoralis Cash et Hopkinson, 1909, Difflugia difficilis Thomas, 1954, Difflugia elegans teres Penard, 1899, Difflugia kempnyi Stepanek, 1953, Difflugia mamma Gassowsky, 1936. D. vietnamica differs from these species by clearly smaller shell length and width (Table 2), higher aperture diameter: shell width ration as well as by presence of some characters. $D$. difficilis, $D$. elegans teres, $D$. kempnyi and D. mamma are distinguished from new species by having aboral horn. In contrast with $D$. amphoralis, $D$. difficilis, $D$. elegans teres, $D$. kemnyi, new species has no apertural collar. In addition, D. elegans teres and $D$. mamma are also differentiated from $D$. vietnamica by presence large sand grains on the shell, while $D$. amphoralis and D. difficilis can be distinguished from $D$. vietnamica by transparency of the shell. Thus, $D$. vietnamica do have unique combination of features that allows to consider this population as a new species for science.

\section{DISCUSSION}

There have been few studies on testate amoebae in Vietnam on relatively small and scattered research areas. This study provides new information on testate amoeba composition from waterbodies of South Vietnam. Samples were collected from different biotopes of different waterbodies spreading over the provinces of southern Vietnam. Temperature, $\mathrm{pH}$, dissolved oxygen and electrical conductivity of water in sampling sites also had a wide range of variation. The surface water temperatures above $30^{\circ} \mathrm{C}$ were often recorded at midday. High values of dissolved oxygen (above $9 \mathrm{mg} / \mathrm{l}$ ) of water were observed at sites where algal bloom or oxygen production of aquatic plants occurred at high water temperatures (above $30^{\circ} \mathrm{C}$ ) and $\mathrm{pH}$ (above 8 ). Electrical conductivities of water $>700 \mu \mathrm{s} / \mathrm{cm}$ were recorded in the waterbodies located close to the sea shore.

The result of this work shows high species richness of the genera Difflugia, Arcella and Centropyxis. Their dominance in freshwaters is also observed in other regions (Yang et al. 2005, 2010; Mazei and Tsyganov 2006b, Todorov et al. 2008, Bobrov et al. 2012a, Davidova and Vasilev 2012, Ju et al. 2014). Previous works (Bobrov et al. 2012a, Tran 2017) also confirm dominance of these genera in the places which are located in investigated region.

Most abundant species in waterbodies of South Vietnam is Centropyxis aculeata. This species is also dominated in other freshwater habitats, such as lakes and ponds of Barbados (Lesser Antilles), the upper Vltava river (Czech republic), Batak Reservoir (Southern Bulgaria), lake Donghu (China) (Roe and Patterson 2006, Holcova 2007, Todorov et al. 2008, Qin et al. 2013). Thus, $C$. aculeata is one of the most common species in many parts of the world.

Netzelia tuberspinifera is considered to be endemic to Asia and only recorded in China so far (Zheng et al. 2013, Gomaa et al. 2015). This species is also observed during current study in lake Ta Mon (province Binh Thuan), lake Buu Long (province Dong Nai) and a small 


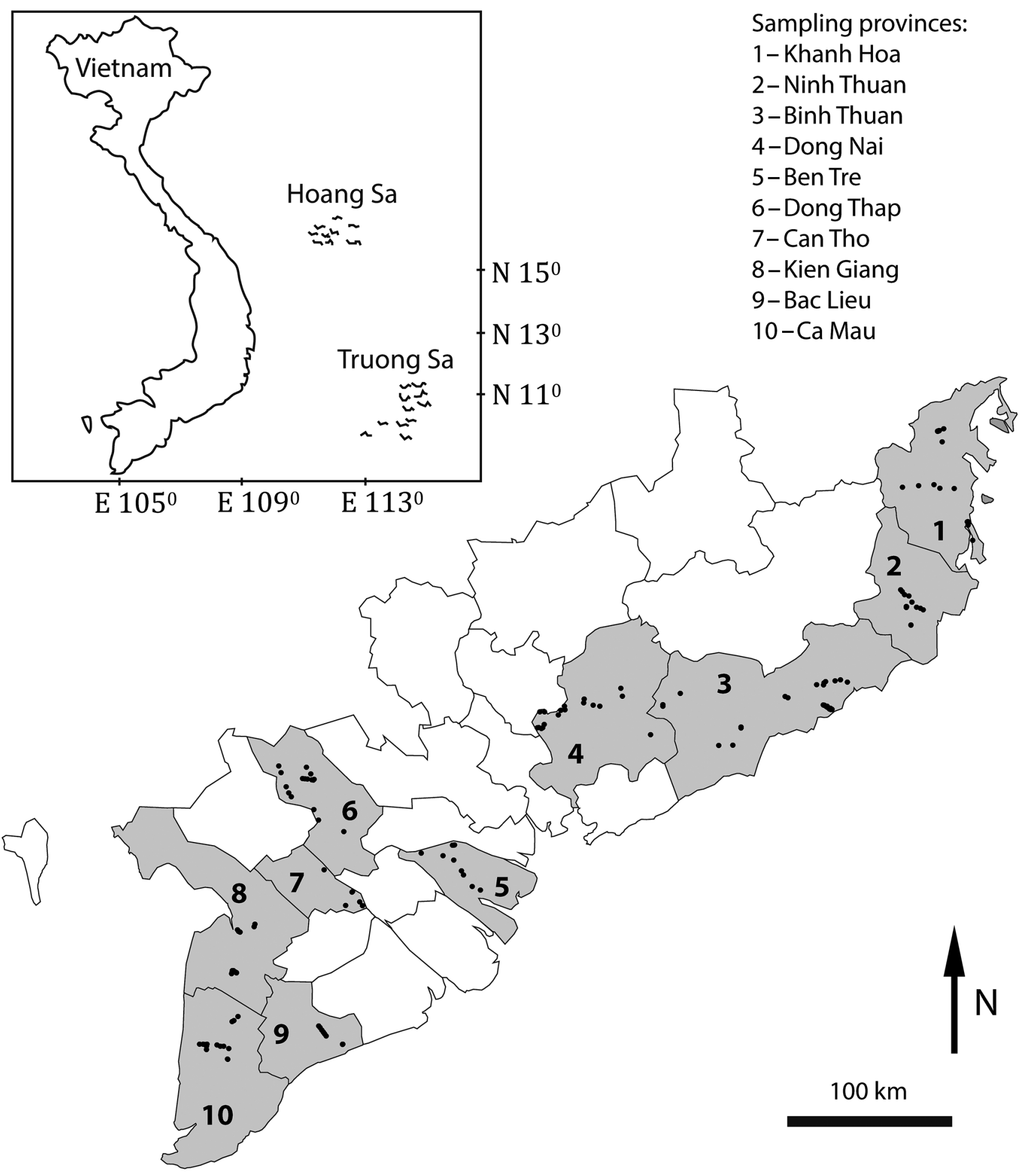

Fig. 1. The scheme of sampling location. Black dots - sampling site. 


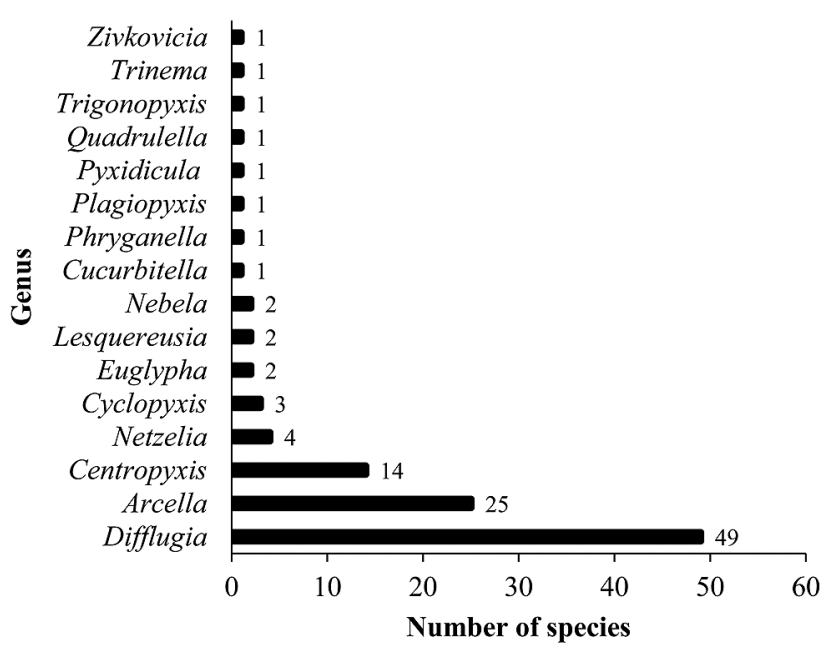

Fig. 2. Species richness of testate amoebae within different genera in waterbodies of South Vietnam.

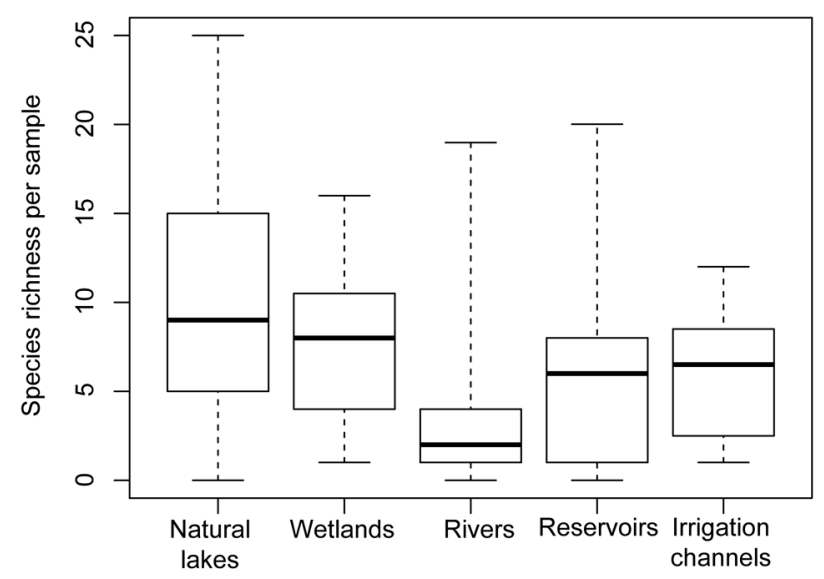

Fig. 3. Boxplot of sample species richness by main types of studied waterbodies.

lake in district Cam Lam (Khanh Hoa). Both spinose and spineless forms of $N$. tuberspinifera were observed in Vietnam for the first time. Zheng et al. (2013) confirmed that two $N$. tuberspinifera morphotypes are not distinguished by morphometric characteristics, but molecular data of Gomaa et al. (2015) shows that they are genetically distinct and closely related. Thus, further researches are required to clarify whether they are actually two different species.

Some rare species of testate amoebae, such as Arcella jurassica, Cyclopyxis plana, Difflugia corniculata, $D$. difficilis, $D$. difficilis ecornis, $D$. kempnyi, D. levanderi, D. lismorensis, D. minuta, D. serbica, Cucurbitel-
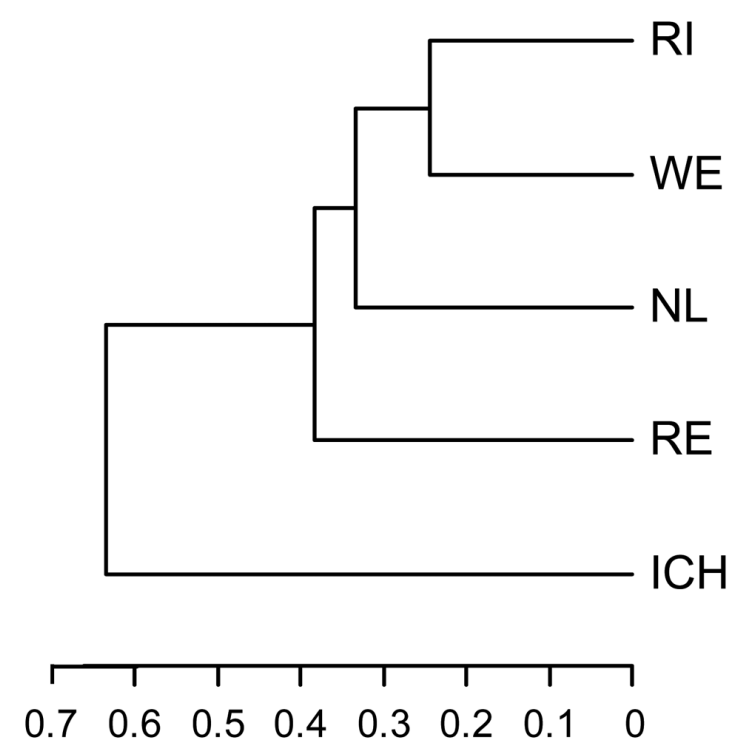

\section{Sørensen index of dissimilarity}

Fig. 4. Dendrogram of cluster analysis (complete linkage). Rivers (RI), wetlands (WE), natural lakes (NL), reservoirs (RE), irrigation channels (ICH).

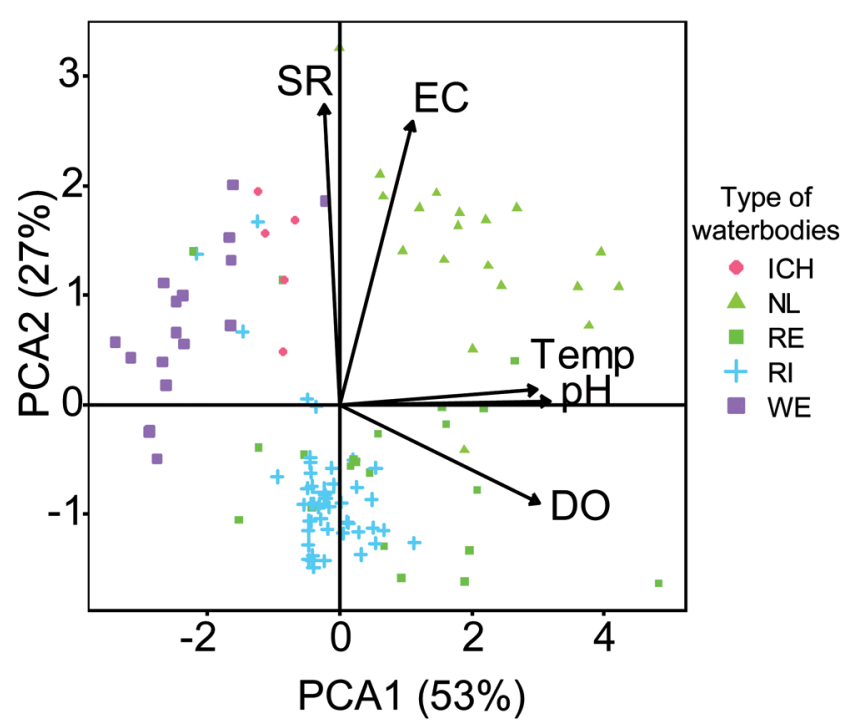

Fig. 5. PCA ordination biplot of testate amoebae samples, species richness (SR) and environmental variables - temperature (Temp), $\mathrm{pH}$, dissolved oxygen (DO), electrical conductivity (EC). Samples were collected from different-type waterbodies: irrigation channels (ICH), natural lakes NL), reservoirs (RE), rivers (RI), wetlands (WE). 
la vlasinensis, Quadrulella debonti, Nebela gracilis are detected in waterbodies of South Vietnam. They were observed in river Cai, lake Suoi Sim (province Khanh Hoa), river Dinh (province Ninh Thuan), lakes Bau Sen and Bau Trang (province Binh Thuan) and wetland of national park Tram Chim (province Dong Thap).

Representatives of species Centropyxis aculeata, Centropyxis aerophila sphagnicola, Centropyxis constricta and Difflugia elegans were observed in brackish water in dead form. Various studies also show the presence of these species in brackish water conditions (Dalby et al. 2000, Ooms et al. 2012, Roe and Patterson 2014).

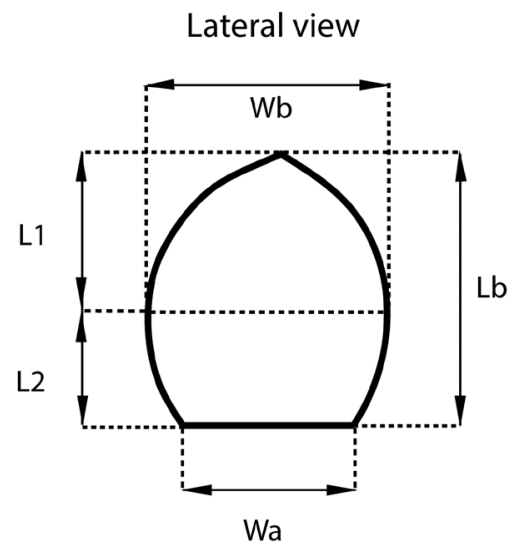

\section{Apertural view}

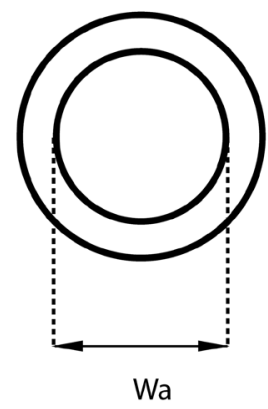

Fig. 6. Outline of Difflugia vietnamica sp. nov. Letters - measured characters (see Table 1).
Although samples were taken in several Vietnamese southern provinces and sampling sites belong to different-type waterbodies, a number of samples are still not enough in relation to the study area. The unsaturated species accumulation curve indicates that the increasing of sampling effort should yield more species of testate amoebae in the investigated area. The alpha-diversity of freshwater testate amoeba communities (number of species per sample) estimated in this work (19.46) was higher than that of the Bau Sau lake (16.79) in Cat Tien National Park, while their beta-diversities are the same (0.33 and 0.35, respectively) (Bobrov et al. 2010).

Species diversity of testate amoebae in natural lakes was highest regardless relatively low number of samples collected from this ecosystem. It may be caused by high habitat heterogeneity of natural lakes affected by high diversity of aquatic macrophytes (Malysheva et al. 2013).

Testate amoebae species richness per sample in rivers is much lower than that of other types of waterbodies, although some riverine samples were characterized by high species richness. However, these samples were collected at standing water places with the presence of alive water hyacinth and grasses. Mazei and Tsyganov (2006a, 2006c) summarized that water velocity may be a limiting factor for testate amoeba distribution. Costa et al. (2011) also show that testate amoeba species richness in lakes is higher than that of rivers.

Table 2. Comparison of Difflugia vietnamica sp. nov. with the most similar species. All measurements are in $\mu \mathrm{m}$.

\begin{tabular}{|c|c|c|c|c|c|c|}
\hline Characters & $\begin{array}{l}\text { Difflugia } \\
\text { vietnamica }\end{array}$ & $\begin{array}{l}\text { Difflugia } \\
\text { amphoralis }\end{array}$ & $\begin{array}{l}\text { Difflugia } \\
\text { difficilis }\end{array}$ & $\begin{array}{l}\text { Difflugia } \\
\text { legans teres }\end{array}$ & $\begin{array}{l}\text { Difflugia } \\
\text { kempnyi }\end{array}$ & $\begin{array}{l}\text { Difflugia } \\
\text { mamma }\end{array}$ \\
\hline Shell length & $49-65$ & $106-114$ & $81-144$ & $120-205$ & $140-230$ & $91-135$ \\
\hline Shell width & $43-53$ & $61-87$ & $20-69$ & $110-150$ & $70-140$ & $37-94$ \\
\hline Apertural width & $23-35$ & $28-43$ & $6-23$ & $60-90$ & $35-60$ & $33-48$ \\
\hline $\begin{array}{l}\text { Apertural width: } \\
\text { shell width ratio }\end{array}$ & 0.60 & 0.48 & 0.33 & 0.58 & 0.44 & 0.51 \\
\hline Shell outline & $\begin{array}{l}\text { Ovoid to elongate- } \\
\text { ovoid with pointed } \\
\text { apex without horn }\end{array}$ & $\begin{array}{l}\text { Pyriform with the } \\
\text { aboral extremity ta- } \\
\text { pering evenly to } \\
\text { a point }\end{array}$ & $\begin{array}{l}\text { Ovoid, circular in } \\
\text { cross-section, very } \\
\text { often with a } \\
\text { few prominent } \\
\text { protuberances }\end{array}$ & Urceolate-ovoid & Urceolate-ovoid & Elongate-ovoid \\
\hline Shell composition & $\begin{array}{l}\text { Small sand } \\
\text { grains }\end{array}$ & $\begin{array}{l}\text { Medium sand } \\
\text { grains }\end{array}$ & $\begin{array}{l}\text { Medium sand } \\
\text { grains }\end{array}$ & $\begin{array}{l}\text { Large sand } \\
\text { grains }\end{array}$ & $\begin{array}{l}\text { Small to medium } \\
\text { sand grains }\end{array}$ & $\begin{array}{l}\text { Small to large sand } \\
\text { grains }\end{array}$ \\
\hline Apertural collar & No & Yes & Yes & Yes & Yes & No \\
\hline Aboral horn & No & No & Yes & Yes & Yes & Yes \\
\hline Data source & This study & $\begin{array}{l}\text { Mazei and Warren } \\
2012\end{array}$ & $\begin{array}{l}\text { Thomas 1954; Mazei } \\
\text { and Warren } 2015\end{array}$ & $\begin{array}{l}\text { Mazei and Tsyganov } \\
2006 \mathrm{a}\end{array}$ & $\begin{array}{l}\text { Mazei and Tsyganov } \\
\text { 2006a }\end{array}$ & $\begin{array}{l}\text { Mazei and Tsyganov } \\
\text { 2006a }\end{array}$ \\
\hline
\end{tabular}



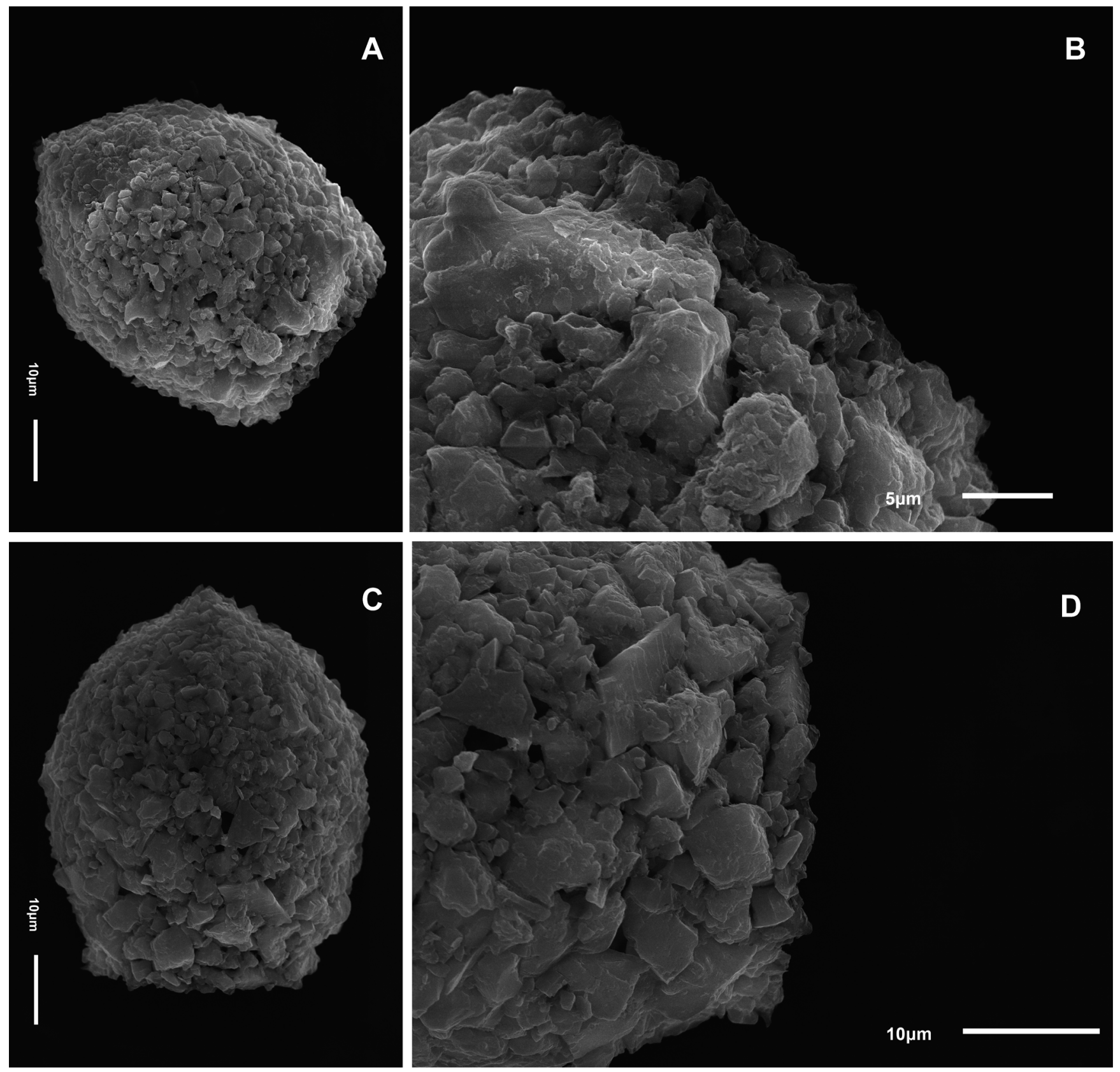

Fig. 7A-D. Scanning electron micrographs of Difflugia vietnamica sp. nov. (A, B) View of shape (A) and view with emphasis on the apertural edge (B) of the first specimen. (C, D) View of shape (C) and view with emphasis on the apertural edge (D) of second specimen.

Relatively high Sørensen similarity index (0.76) between wetlands and rivers represent an interesting result because of the major differences between these two types of waterbodies. This may indicate the existence of hidden common characteristics of microhabitat niches for testate amoebae in both ecosystems.
The relationships between testate amoeba community and environmental variables have been investigated in various studies. Results of many investigations show low relation between testate amoeba community and water temperature (Mattheeussen et al. 2005, Mieczan 2009, Ju et al. 2014), pH (Booth 2001, Jassey et 
al. 2011, Qin et al. 2013b, Song et al. 2014), dissolved oxygen (Warner et al. 2007, Mieczan and Adamczuk 2015, Swindles et al. 2015), electrical conductivity (Lamentowicz and Mitchell 2005, Escobar et al. 2008, Qin et al. 2013a, Swindles et al. 2015). Similarly, the results of the present study show a weak relationship between sample species richness and listed environmental variables. This may be explained by the fact, that environmental data in most studies were obtained at the moment of sampling in short time periods. Thus, measured environmental parameters do not represent variations of habitat conditions, which really affect testate amoeba communities. Thus, temporal variations of environmental parameters in microhabitats of testate amoeba communities should be considered in further investigations.

Acknowledgments. The authors would like to thank Dr. Denis V. Tikhonenkov for fruitful discussions and valuable suggestions, Dmitry Zagumyonnyi for SEM images, Dr. Elena Malysheva and Mr. Ferry Siemensma for their help in the testate amoeba identification, and Vu T. Dao, Dien D. Tran for their help in the sample collection. This study was supported by the Vietnamese-Russian Tropical Centre (Grant number 302/QĐ-CNVB) and the Russian Science Foundation (Grant number 14-50-00029).

Supplementary data. Supplementary data associated with this article are included at the end of this online article.

\section{REFERENCES}

Balik V. (1995) Testate amoebae (Protozoa: Rhizopoda) from a primary mountain rain forest in the Tam-Dao region (Vietnam). Acta Soc. Zool. Bohem. 59: 1-16

Bobrov A. A., Mazei Y. A., Tiunov A.V. (2010) Testate amoebae of a monsoon tropical forest of South Vietnam. Acta Protozool. 49: $311-325$

Bobrov A., Kosakyan A. (2015) A new species from mountain forest soils in Japan: Porosia paracarinata sp. nov., and taxonomic concept of the genus Porosia Jung, 1942. Acta Protozool. 54: 289-294

Bobrov A., Mazei Y., Chernyshov V., Gong Y., Feng W. (2012a) Testate amoebae communities from some freshwater and soil habitats in China (Hubei and Shandong Provinces). Front. Earth Sci. 6: 1-9

Bobrov A., Shimano S., Mazei Y. (2012b) Two new species of testate amoebae from mountain forest soils of Japan and redescription of the genus Deharvengia Bonnet, 1979. Acta Protozool. 51: $55-63$

Booth R. K. (2001) Ecology of testate amoebae (Protozoa) in two lake superior coastal wetlands: implications for paleoecology and environmental monitoring. Wetlands. 21: 564-576

Charman D. J., Hendon D., Woodland W. A. (2000) The identification of testate amoebae (Protozoa: Rhizopoda) in peats. QRA Technical Guide № 9. Quaternary Research Association, London
Costa D. de M., Alves G. M., Velho L. F. M., Lansac-Toha F. A. (2011) Species richness of testate amoebae in different environments from the upper Paraná river floodplain (PR/MS). Acta Sci. Biol. Sci. 33: 263-270

Dalby A. P., Kumar A., Moore J. M., Patterson R. T. (2000) Preliminary survey of arcellaceans (thecamoebians) as limnological indicators in tropical lake Sentani, Irian Jaya, Indonesia. J. Foramin. Res. 30: 135-142

Davidova R. D., Vasilev V. M. (2012) Composition and structure of Testate amoebae fauna (Protozoa: Arcellinida and Euglyphida) in Durankulak lake (Northeastern Bulgaria). Ecologia Balkanica. 4: 73-80

Escobar J., Brenner M., Whitmore T. J., Kenney W. F., Curtis J. H. (2008) Ecology of testate amoebae (thecamoebians) in subtropical Florida lakes. J. Paleolimnol. 40: 715-731

Golemansky V. (1979) Thécamoebiens psammobiontes du supralittoral vietnamien de la Mer Chinoise et description de Cryptodifflugia brevicolla sp. n. (Rhizopoda: Arcellinida). Acta Protozool. 18: 285-292

Gomaa F., Yang J., Mitchell E. A. D., Zhang W., Yu Z., Todorov M., Lara E. (2015) Morphological and molecular diversification of Asian endemic Difflugia tuberspinifera (Amoebozoa, Arcellinida): A case of fast morphological evolution in protists?. Protist. 166: $122-130$

Holcova K. (2007) Thecamoebians from the Upper Vltava river (Sumava mountains, Czech republic): species composition of assemblages vs. environment in streams. J. Foramin. Res. 37: 287-299

Jassey V. E. J., Chiapusio G., Mitchell E. A. D., Binet P., Toussaint M., Gilbert D. (2011) Fine-scale horizontal and vertical microdistribution patterns of testate amoebae along a narrow fen/bog gradient. Microb. Ecol. 61: 374-385

Ju L., Yang J., Liu L., Wilkinson D. M. (2014) Diversity and distribution of freshwater testate Amoebae (Protozoa) along latitudinal and trophic gradients in China. Microb. Ecol. 68: 657-670

Kassambara A. (2017) Practical guide to principal component methods in R (Multivariate analysis) (Volume 2). CreateSpace Independent Publishing Platform

Kim S., Park M. G. (2016) Paulinella longichromatophora sp. nov., a new marine photosynthetic testate amoeba containing a chromatophore. Protist. 167: 1-12

Kudo R. R. (1939) Protozoology. Handbook of protozoology. Charles C. Thomas Publisher

Lamentowicz M., Mitchell E. A. D. (2005) The ecology of testate amoebae (protists) in Sphagnum in North-western Poland in relation to peatland ecology. Microb. Ecol. 50: 48-63

Malysheva E., Mazei Y., Yermokhin M. (2013) Testate amoebae community pattern in different types of boundary structures at the water-land contact zone. Biol. Bull. 40: 823-831

Mattheeussen R., Ledeganck P., Vincke S., Van de Vijver B., Nijs I., Beyns L. (2005) Habitat selection of aquatic testate amoebae communities on Qeqertarsuaq (Disko Island), West Greenland. Acta Protozool. 44: 253-263

Mazei Y., Tsyganov A. (2006a) Freshwater testate amoebae. KMK Sci. Press, Moscow (in Russian)

Mazei Y., Tsyganov A. (2006b) Testate amoebae from freshwater ecosystems of the Sura River basin (Middle Volga Region). 1. Fauna and morphological-ecological characteristics of species. Zool. Zhurn. 85: 1267-1280 (in Russian with English summary)

Mazei Y., Tsyganov A. (2006c) Testate amoebae from freshwater ecosystems of the Sura River basin (Middle Volga Region). 
2. Community structure. Zool. Zhurn. 85: 1395-1401 (in Russian with English summary)

Mazei Y., Warren A. (2012) A survey of the testate amoeba genus Difflugia Leclerc, 1815 based on specimens in the E. Penard and C.G. Ogden collections of the Natural History Museum, London. Part 1: Species with shells that are pointed aborally and/or have aboral protuberances. Protistology. 7: 121-171

Mazei Y., Warren A. (2014) A survey of the testate amoeba genus Difflugia Leclerc, 1815 based on specimens in the E. Penard and C.G. Ogden collections of the Natural History Museum, London. Part 2: Species with shells that are pyriform or elongate. Protistology. 8: 133-171

Mazei Y., Warren A. (2015) A survey of the testate amoeba genus Difflugia Leclerc, 1815 based on specimens in the E. Penard and C.G. Ogden collections of the Natural History Museum, London. Part 3: Species with shells that are spherical or ovoid. Protistology. 9: 3-49

Mieczan T. (2009) Ecology of testate amoebae (Protists) in Sphagnum peatlands of eastern Poland: Vertical micro-distribution and species assemblages in relation to environmental parameters. Ann. Limnol. - Int. J. Lim. 45: 41-49

Mieczan T., Adamczuk M. (2015) Ecology of testate amoebae (Protists) in mosses: distribution and relation of species assemblages with environmental parameters (King George Island, Antarctica). Polar Biol. 38: 221-230

Nguyen V. H., Bernard N., Mitchell E. A. D., Cortet J., Badot P. M., Gilbert D. (2007) Relationship between testate amoeba (Protist) communities and atmospheric heavy metals accumulated in Barbula indica (Bryophyta) in Vietnam. Microb. Ecol. 53: $53-65$

Oksanen J., Blanchet F. G., Friendly M., Kindt R., Legendre P., McGlinn D., Minchin P. R., O'Hara R. B., Simpson G. L., Solymos P., Stevens M. H. H., Szoecs E., Wagner H. (2018) vegan: Community Ecology Package

Ooms M., Beyens L., Temmerman S. (2012) Testate amoebae as proxy for water level changes in a brackish tidal marsh. Acta Protozool. 51: 271-289

Qin Y., Fournier B., Lara E., Gu Y., Wang H., Cui Y., Zhang X., Mitchell E. A. D. (2013a) Relationships between testate amoeba communities and water quality in Lake Donghu, a large alkaline lake in Wuhan, China. Front. Earth Sci. 7: 182-190

Qin Y., Man B., Kosakyan A., Lara E., Gu Y., Wang H., Mitchell E. A. D. (2016) Nebela jiuhuensis nov. sp. (Amoebozoa; Arcellinida; Hyalospheniidae): A new member of the Nebela saccifera - equicalceus - ansata group described from sphagnum peatlands in South-Central China. J. Eukaryot. Microbiol. 0: $1-9$

Qin Y., Mitchell E. A. D., Lamentowicz M., Payne R. J., Lara E., Gu Y., Huang X., Wang H. (2013b) Ecology of testate amoebae in peatlands of central China and development of a transfer function for paleohydrological reconstruction. J. Paleolimnol. 50: 319-330

Qin Y., Xie S., Gu Y., Zhou X. (2008a) Pontigulasia pentangulostoma nov. spec., a new testate amoeba from the Da Jiuhu peatland of the Shennongjia moutains, China. Acta Protozool. 47: $155-160$
Qin Y., Xie S., Swindles T. G., Gu Y., Zhou X. (2008b) Pentagonia zhangduensis nov. spec. (Lobosea, Arcellinida), a new freshwater species from China. Eur. J. Protistol. 44: 287-290

Roberts D. W. (2016) labdsv: Ordination and Multivariate Analysis for Ecology

Roe H. M., Patterson R. T. (2014) Arcellacea (Testate Amoebae) as bio-indicators of road salt contamination in lakes. Microb. Ecol. 68: 299-313

Roe H. M., Patterso, R. T. (2006) Distribution of thecamoebians (Testate amoebae) in small lakes and ponds, Barbados, West Indies. J. Foramin. Res. 36: 116-134

Shirota A. (1966) The plankton of South Viet-Nam: Fresh water and marine plankton. Overseas Technical Cooperation Agency, Japan

Song L., Li H., Wang K., Wu D., Wu H. (2014) Ecology of testate amoebae and their potential use as palaeohydrologic indicators from peatland in Sanjiang Plain, Northeast China. Front. Earth Sci. 8: $564-572$

Swindles G. T., Turner T. E., Carrivick J. L., Woulds C., Parry L., Holden J., Amesbury M. J., Roland T. P., Charman D. J., Raby C., Mullan D., Galloway J. M., Kokfelt U., Garneau M. (2015) Evaluating the use of testate amoebae for palaeohydrological reconstruction in permafrost peatlands. Palaeogeogr. Palaeoclimatol. Palaeoecol. 424: 111-122

Team R. C. (2017) R: A language and environment for statistical computing. R Foundation for Statistical Computing, Vienna, Austria

Thomas R. (1954) Thécamoebiens de la region bordelaise. Bull. Soc. Hist. Natur. Toulouse. 89: 245-264

Todorov M., Golemansky V., Temelkov B. (2008) Diversity and biotopic distribution of testate amoebae (Protozoa: Arcellinida and Euglyphida) in the Batak Reservoir (Southern Bulgaria). Acta zool. bulg. 60: 115-124

Tran Q. H. (2017) Diversity and community patterns of testate amoebae in Bau Sen and Bau Trang lakes in Binh Thuan Province, Vietnam. Inland Water Biol. 10: 1-7

Warner B. G., Asada T., Quinn N. P. (2007) Seasonal influences on the ecology of testate amoebae (protozoa) in a small sphagnum peatland in Southern Ontario, Canada. Microb. Ecol. 54: 91-100

Yang J., Smith H. G., Wilkinson D. M. (2010) Fauna and distribution of Testacea (Protozoa) from Arctic, Antarctic and Tibet. Biodiversity Science. 18: 373-382

Yang J., Zhang W. J., Feng W. S., Shen Y. F. (2005) Freshwater testate amoebae of nine Yunnan Plateau lakes, China. J. Freshwater Ecol. 20: 743-750

Yu Z., Zhang W., Liu L., Yang J. (2014) Evidence for two different morphotypes of Difflugia tuberspinifera from China. Eur. J. Protistol. 50: 205-211

Received on $14^{\text {th }}$ September, 2018; revised on $18^{\text {th }}$ November, 2018; accepted on $5^{\text {th }}$ December, 2018 
Supplementary Table 1. Frequency of occurrence (\%) of identified testate amoebae

\begin{tabular}{|c|c|c|c|}
\hline № & Species & New records for Vietnam & $\begin{array}{c}\text { Occurrence } \\
(\%)\end{array}$ \\
\hline & ARCELLIDAE Ehrenberg, 1843 & & \\
\hline 1 & Arcella arenaria Greeff, 1866 & & 5.2 \\
\hline 2 & Arcella discoides Ehrenberg, 1843 & & 25.6 \\
\hline 3 & Arcella discoides difficilis Deflandre, 1928 & & 2.6 \\
\hline 4 & Arcella discoides pseudovulgaris Deflandre, 1928 & & 4.2 \\
\hline 5 & Arcella discoides pseudovulgaris arcuata Deflandre, 1928 & & 3.1 \\
\hline 6 & Arcella discoides scutelliformis Playfair, 1918 & & 7.8 \\
\hline 7 & Arcella gibbosa Penard, 1890 & & 1.6 \\
\hline 8 & Arcella hemisphaerica Perty, 1852 & & 9.4 \\
\hline 9 & Arcella hemisphaerica playfairiana Deflandre, 1928 & & 0.5 \\
\hline 10 & Arcella intermedia (Deflandre, 1928) Tsyganov et Mazei, 2006 & & 15.7 \\
\hline 11 & Arcella intermedia laevis (Deflandre, 1928) Tsyganov et Mazei, 2006 & & 9.9 \\
\hline 12 & Arcella jurassica Olivier, 1945 & + & 0.5 \\
\hline 13 & Arcella megastoma Penard, 1902 & & 5.8 \\
\hline 14 & Arcella megastoma arcuata Deflandre, 1928 & + & 1.6 \\
\hline 15 & Arcella mitrata spectabilis Deflandre, 1928 & & 6.8 \\
\hline 16 & Arcella polypora Penard, 1890 & & 4.2 \\
\hline 17 & Arcella rotundata Playfair, 1918 & & 3.1 \\
\hline 18 & Arcella sp. & & 0.5 \\
\hline 19 & Arcella vulgaris Ehrenberg, 1830 & & 12.6 \\
\hline 20 & Arcella vulgaris crenulata Deflandre 1928 & + & 0.5 \\
\hline 21 & Arcella vulgaris penardi Deflandre, 1928 & + & 3.7 \\
\hline 22 & Arcella vulgaris polymorpha Deflandre, 1928 & & 1.1 \\
\hline 23 & Arcella cf. vulgaris crenulata & & 2.6 \\
\hline 24 & Arcella $\mathrm{cf}$. vulgaris penardi & & 0.5 \\
\hline 25 & Arcella vulgaris wailesi Deflandre, 1928 & + & 0.5 \\
\hline \multirow[t]{2}{*}{26} & Pyxidicula operculata (Agardh, 1827) Ehrenberg, 1834 & & 0.5 \\
\hline & CENTROPYXIDAE Jung, 1942 & & \\
\hline 27 & Centropyxis aculeata (Ehrenberg, 1832) Stein, 1857 & & 68.1 \\
\hline 28 & Centropyxis aculeata grandis Deflandre, 1929 & & 1.6 \\
\hline 29 & Centropyxis aculeata minima van Oye, 1958 & & 1.6 \\
\hline 30 & Centropyxis aculeata tropica Deflandre, 1929 & & 1.1 \\
\hline 31 & Centropyxis aculeata oblonga Deflandre, 1929 & & 0.5 \\
\hline 32 & Centropyxis aerophila Deflandre, 1929 & & 0.5 \\
\hline 33 & Centropyxis aerophila sphagnicola Deflandre, 1929 & & 27.2 \\
\hline 34 & Centropyxis cassis (Wallich, 1864) Deflandre, 1929 & & 2.1 \\
\hline 35 & Centropyxis cassis spinifera (Playfair, 1918) Deflandre, 1929 & & 0.5 \\
\hline 36 & Centropyxis constricta (Ehrenberg, 1841) Deflandre, 1929 & & 15.2 \\
\hline 37 & Centropyxis ecornis (Ehrenberg, 1841) Leidy, 1879 & & 12.0 \\
\hline 38 & Centropyxis elongata (Penard, 1890) Thomas, 1959 & & 14.7 \\
\hline 39 & Centropyxis laevigata Penard, 1890 & & 15.2 \\
\hline 40 & Centropyxis marsupiformis (Wallich, 1864) Deflandre, 1929 & + & 3.7 \\
\hline 41 & Cyclopyxis eurystoma Deflandre, 1929 & & 6.8 \\
\hline 42 & Cyclopyxis kahli Deflandre, 1929 & & 15.2 \\
\hline 43 & Cyclopyxis plana Bartos, 1963 & & 5.8 \\
\hline 44 & Trigonopyxis arcula (Leidy, 1879) Penard, 1912 & & 1.1 \\
\hline
\end{tabular}


DIFFLUGIIDAE Wallich, 1864

Difflugia acuminata Ehrenberg, 1838

Difflugia amphoralis Cash et Hopkinson, 1909

Difflugia ampullula Playfair, 1918

Difflugia avellana Penard, 1890

Difflugia bicornis Penard, 1890

Difflugia brevicolla Cash et Hopkinson, 1909

Difflugia bryophila (Penard, 1902) Jung, 1942

Difflugia capreolata Penard, 1902

Difflugia claviformis Penard, 1899

Difflugia corniculata Gauthier-Lievre et Thomas, 1958

Difflugia curvicaulis Penard, 1899

Difflugia cylindrus (Thomas, 1953) Ogden, 1983

Difflugia difficilis Thomas, 1954

Difflugia difficilis ecornis Chardez, 1956

Difflugia elegans Penard, 1890

Difflugia elegans angustata Gauthier-Lievre et Thomas, 1958

Difflugia gigantea (Chardez, 1967) Ogden et Fairman, 1979

Difflugia globulosa Dujardin, 1837

Difflugia gramen Penard, 1902

Difflugia kempnyi Stepanek, 1953

Difflugia lanceolata Penard, 1890

Difflugia levanderi Playfair, 1918

Difflugia limnetica Penard, 1902

Difflugia linearis (Penard, 1890) Gauthier-Lievre et Thomas, 1958

Difflugia lingula regularis Gauthier-Lievre et Thomas, 1958

Difflugia lismorensis Playfair, 1918

Difflugia lithophila (Penard, 1902) Gauthier-Lievre et Thomas, 1958

Difflugia lobostoma Leidy, 1879

Difflugia minuta Rampi, 1950

Difflugia oblonga Ehrenberg, 1838

Difflugia parva (Thomas, 1954) Ogden, 1983

Difflugia paulii Ogden, 1983

Difflugia penardi Hopkinson, 1909

Difflugia petricola Cash, 1909

Difflugia pyriformis Perty, 1849

Difflugia schurmanni van Oye, 1932

Difflugia serbica Ogden et Zivkovic, 1983

Difflugia sp.1

Difflugia $\mathrm{sp} .2$

Difflugia sp.3

Difflugia urceolata Carter, 1864

Difflugia urceolata lageniformis Wallich, 1864

Difflugia urceolata sphaerica Playfair, 1917

Difflugia venusta (Penard, 1902) Ogden, 1983

Difflugia ventricosa Deflandre, 1926

Difflugia vietnamica sp. nov.

Cucurbitella vlasinensis Ogden et Zivkovic, 1983

Zivkovicia compressa (Carter, 1864) Ogden, 1987 
HYALOSPHENIIDAE (Schultze, 1877) Kosakyan and Lara 2012

LESQUEREUSIDAE Ogden, 1979

\section{Lesquereusia modesta Rhumbler, 1895}

Lesquereusia spiralis (Ehrenberg, 1840) Butschli, 1888

Netzelia corona (Wallich, 1864) Gomaa et al., 2017

Netzelia corona crenulata (Gauthier-Lievre et Thomas, 1958) Gomaa et al., 2017

Netzelia oviformis (Cash, 1909) Ogden, 1979

Netzelia sp.

Netzelia tuberculata (Wallich, 1864) Netzel, 1983

Netzelia wailesi (Ogden, 1980) Meisterfeld, 1984

PHRYGANELLIDAE Jung, 1942

Phryganella acropodia (Hertwig et Lesser, 1874) Hopkinson, 1909

PLAGIOPYXIDAE Bonnet et Thomas, 1960

\section{Plagiopyxis sp.}

EUGLYPHIDAE Wallich, 1864

Euglypha acanthophora (Ehrenberg, 1841) Perty, 1849

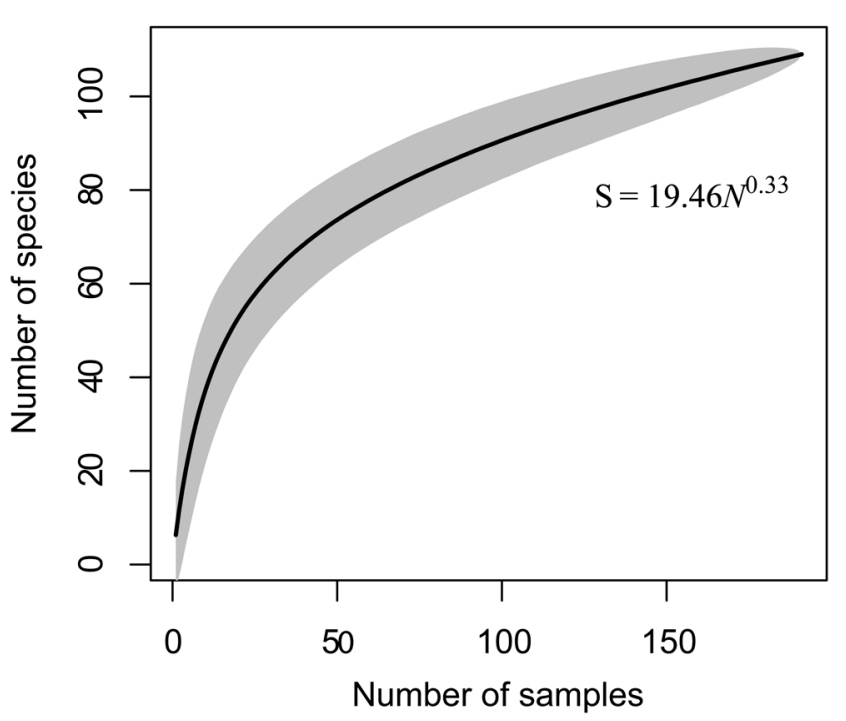

Supplementary Figure 1. Relationships between a number of identified species and sampling effort.

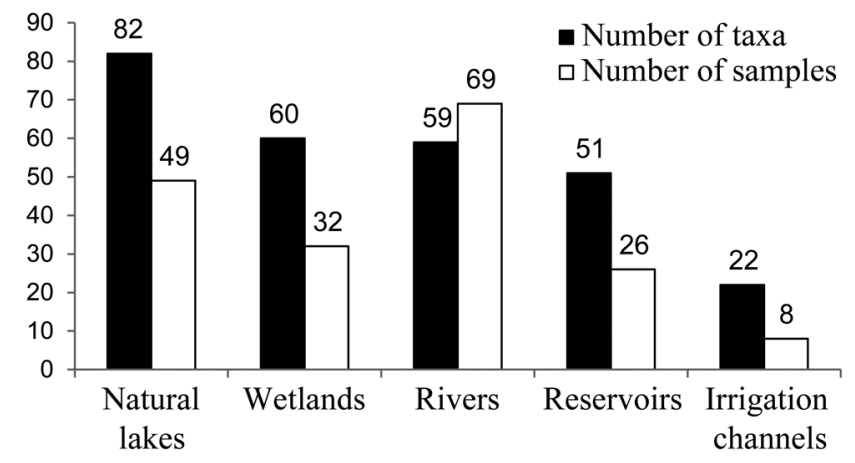

Supplementary Figure 2. Number of identified species of testate amoebae in main types of studied waterbodies. 

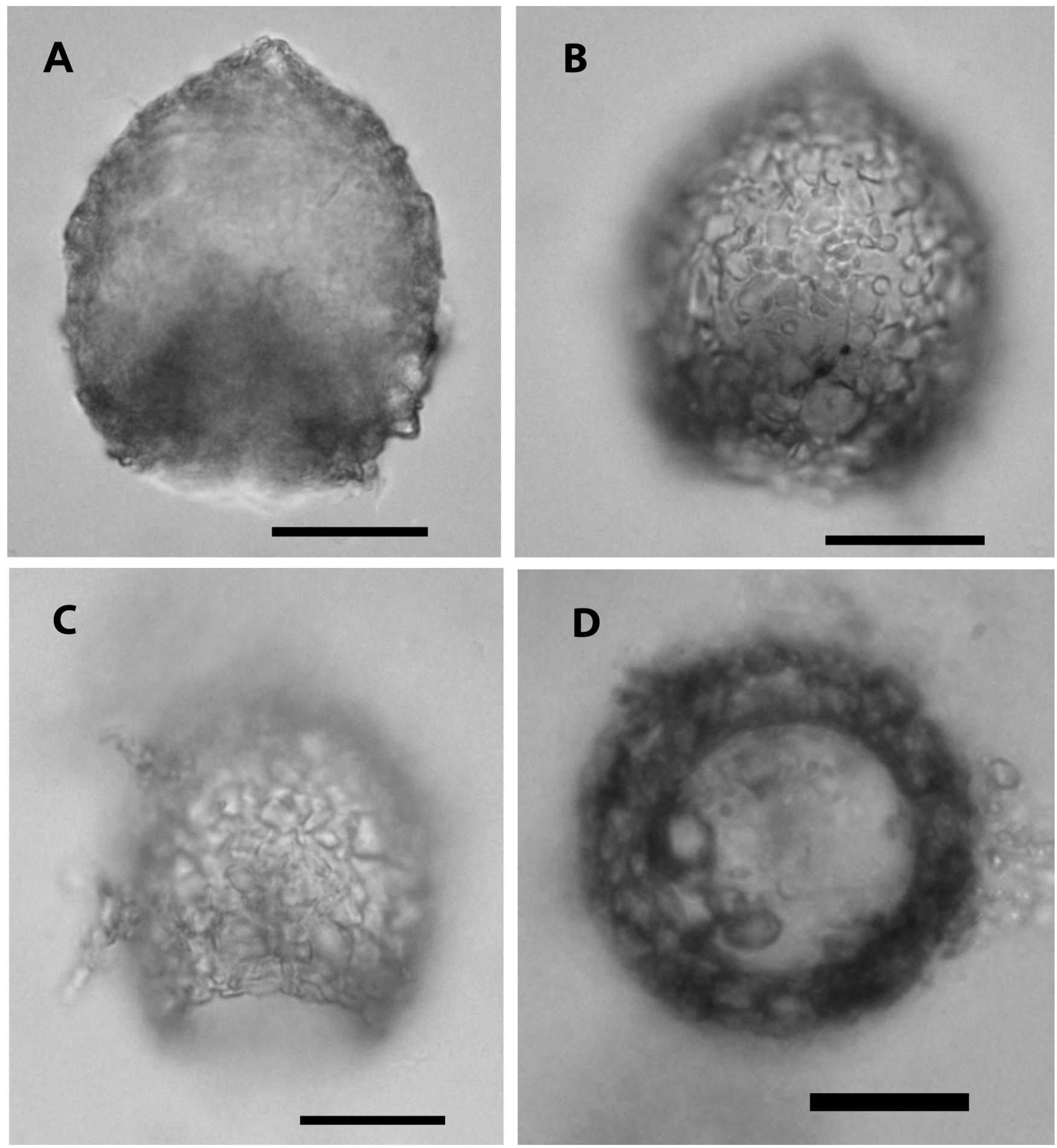

Supplementary Figure 3A-D. Light microscopical micrographs of Difflugia vietnamica sp. nov. (A) View of the shape. (B) View with emphasis on the side surface. (C) View with emphasis on the apertural edge. (D) Apertural view. Scale bars: $20 \mu \mathrm{m}$. 




Supplementary Figure 4. Density and normal Q-Q plots of measured morphological characters of Difflugia vietnamica sp. nov. Lb, L1, $\mathrm{L} 2, \mathrm{~Wb}$ and $\mathrm{Wa}$ - measured characters (see Table 1). N - number of measured specimens. $\mathrm{p}$ - simulated p-value (based on 2000 replicates) from Hartigans' dip test for unimodality (function 'dip.test' of R package 'diptest'). $\mathrm{p}>0.05$ indicates unimodal distribution of measured morphological character. 